\title{
„Biblioteka ucząca się" - zmiany w organizacji i systemie zarządzania w Bibliotece Uniwersytetu Finlandii Wschodniej
}

Streszczenie. Zmieniające się, dynamiczne i wymagające otoczenie współczesnej biblioteki naukowej wywiera nacisk na procesy innowacyjne związane ze zmianami modelu zarządzania. Tematem artykułu są zmiany w organizacji i systemie zarządzania w Bibliotece Uniwersytetu Finlandii Wschodniej przeprowadzone w związku z fuzją poszczególnych jednostek bibliotecznych. W artykule opisano przeobrażenia na poziomie struktury organizacyjnej, polityki gromadzenia, przechowywania i udostępniania zbiorów oraz $\mathrm{w}$ zakresie zarządzania zasobami ludzkimi w kontekście koncepcji organizacji uczącej się, która potrafi funkcjonować w niestabilnym otoczeniu, dostosowuje się do zmian, ale także poszukuje alternatywy zapewniającej ciągłość i rozwój organizacji.

SŁOWA KLuczowe: Biblioteka Uniwersytetu Finlandii Wschodniej, National Repository Library, Biblioteka Uniwersytecka w Kuopio, Biblioteka Uniwersytecka w Joensuu, organizacja ucząca się, zmiana.

Otoczenie organizacji jest systemem i jak każdy system składa się z różnych elementów oraz wzajemnych, często skomplikowanych, powiązań. Relacje między elementami zachodzą w różnych kierunkach, co powoduje ciągłe zmiany w ramach systemu. Podstawową cechą otoczenia - jako elementu systemu - jest jego niestabilność, turbulencja. W konsekwencji kluczowe zdarzenia zachodzące w otoczeniu organizacji stają się coraz bardziej nowatorskie, kosztowne, szybkie i trudne do przewidzenia ${ }^{1}$. Turbulentne otoczenie wywiera nacisk na procesy innowacyjne związane ze

${ }^{1}$ B. Jasiński, Elastyczność organizacji jako odpowiedź na turbulentne otoczenie, w: Zarzadzanie przedsiębiorstwem w turbulentnym otoczeniu, red. R. Krupski, Warszawa 2005, s. 15. 
zmianami w modelu zarządzania organizacją. Odpowiedzią na takie wyzwanie jest koncepcja organizacji uczącej się, która potrafi funkcjonować w niestabilnym otoczeniu, dostosowuje się do zmian, ale także poszukuje alternatywy zapewniającej jej ciągłość i rozwój². Jednym z przykładów organizacji uczącej się w wymiarze indywidualnym, zespołowym i organizacyjnym może być Biblioteka Uniwersytetu Finlandii Wschodniej (BUFW). Wiele przeobrażeń na poziomie struktury organizacyjnej, polityki gromadzenia, przechowywania i udostępniania zbiorów oraz w zakresie zarządzania zasobami ludzkimi udowodniło, że biblioteka ta jest organizacja która ciągle rozszerza możliwości w zakresie kreowania własnej przyszłości oraz przywiązuje dużą wagę do niezawodności, zmian adaptacyjnych i elastyczności ${ }^{3}$.

\section{Powstanie Biblioteki Uniwersytetu Finlandii Wschodniej}

Struktura fińskiego systemu szkolnictwa wyższego opiera się na sektorze uniwersyteckim i politechnicznym. Pierwszy z nich obejmuje 20 uczelni, które znajdują się m.in. w Helsinkach, Turku, Tampere, Kuopio, Oulu, Jyväskylä, Joensuu, Rovaniemi i Vasaa. Najstarszy, a zarazem największy tradycyjny fiński uniwersytet mieści się w Helsinkach. Został on stworzony na kanwie Akademii Królewskiej powstałej w 1640 roku w Turku.

Na początku lat 90. XX wieku integralną częścią jednostek szkolnictwa wyższego stawały się różne rodzaje systemów zarządzania jakością. Proces ten rozwinął się w 1999 roku, kiedy ministrowie edukacji 29 krajów, w tym Finlandii, podpisali Deklarację Bolońską czyli dokument zawierający zadania prowadzące do ujednolicenia systemów szkolnictwa wyższego krajów europejskich. Głównym celem Deklaracji Bolońskiej było stworzenie do 2010 roku Europejskiego Obszaru Szkolnictwa Wyższego, co doprowadziło do ustanowienia odpowiedniej polityki wprowadzenia tych zasad w każdym kraju członkowskim. Fińskie Ministerstwo Edukacji zobowiązało wówczas uczelnie wyższe do wdrażania systemu zarządzania jakościa, którego audyt przeprowadzany jest raz $\mathrm{w}$ roku. W 2006 roku ministerstwo opublikowało zasady strukturalnego rozwoju szkół wyższych. Głównym celem projektu było zredukowanie ich liczby przez włączanie mniejszych jednostek uniwersyteckich do większych. Dodatkowym zamierzeniem było uzyskanie większej autonomii szkół

2 E. Stańczyk-Hugiet, Organizacja uczaca się, w: Zarządzanie przedsiębiorstwem w turbulentnym otoczeniu, red. R. Krupski, Warszawa 2005, s. 223.

${ }^{3}$ Ibidem, s. 195. 
wyższych dzięki ogólnemu wzrostowi poziomu konkurencyjności fińskiego systemu szkolnictwa wyższego.

W związku ze zmianami strukturalnymi w 2010 roku trzy fińskie uczelnie: Uniwersytet $\mathrm{w}$ Kuopio, Uniwersytet w Joensuu i Uniwersytet w Savonlinna zostały połączone i stworzyły Uniwersytet Finlandii Wschodniej, będący jednym z największych uniwersytetów w kraju. Nowa uczelnia obejmuje kilka wydziałów: filozoficzny, przyrodniczy i leśny, nauk o zdrowiu, nauk społecznych i zarządzania. Obecnie kształci się na niej około 14 tysięcy studentów, w tym 6 tysięcy w kampusie uniwersyteckim w Kuopio i 8 tysięcy $\mathrm{w}$ kampusie uniwersyteckim $\mathrm{w}$ Joensuu. Uczelnia zatrudnia 3 tysiące pracowników, z czego 1,8 tysiąca pracuje w Kuopio, a 1,2 tysiąca w Joensuu.

Po fuzji uniwersytetów także biblioteki uczelniane stanęły przed koniecznością utworzenia jednej instytucji. Nowa biblioteka funkcjonuje od 2010 roku pod nazwą Biblioteka Uniwersytetu Finlandii Wschodniej i obejmuje: Bibliotekę Uniwersytecką w Kuopio, Bibliotekę Uniwersytecką w Joensuu, Bibliotekę Uniwersytecką w Savonlinna i Bibliotekę Medyczną Szpitala Uniwersyteckiego w Kuopio. Wymienione jednostki oddalone są od siebie o około $140 \mathrm{~km}$.

Biblioteka Uniwersytecka w Kuopio powstała w 1972 roku. Jej roczny budżet wynosi około 3 miliony euro. Biblioteka zatrudnia 35 pracowników. Zbiory obejmują 143 tysiące monografii, 800 czasopism w wersji drukowanej, 14,5 tysiąca czasopism w wersji elektronicznej, 50 tysięcy e-booków oraz 5,5 tysiąca materiałów audiowizualnych i innych. Biblioteka gromadzi księgozbiór głównie z zakresu: medycyny, nauk przyrodniczych i farmacji ${ }^{4}$.

W Bibliotece Uniwersyteckiej w Joensuu pracuje 45 osób. Gromadzony księgozbiór dotyczy: humanistyki, edukacji, nauk społecznych, teologii i prawa. Podkreślenia wymaga fakt, iż w bibliotece znajduje się jedna z najokazalszych kolekcji Kalewali - fińskiego eposu narodowego - której autorem jest Elias Lönnrot, żyjący w XIX wieku. Dzieło jest efektem 12 wycieczek pisarza do wschodniej i północno-wschodniej części Finlandii. Kalewala to zbiór legend i pieśni ludowych, zestawionych w jedną długą narracyjną opowieść. Istnieje około 600 wersji Kalewali, a także blisko 60 jej przekładów ${ }^{5}$.

W trzeciej bibliotece składowej BUFW - Bibliotece Uniwersyteckiej w Savonlinna-znajduje się księgozbiór z zakresu pedagogiki i psychologii.

${ }^{4}$ J. Saarti, A. Juntunen, A. Taskinen, Multi-faceted measuring of the quality as a tool for quality improvement in the Kuopio University Library, Finland, "Performance Measurement and Metrics" 2010, t. 11, nr 1, s. 40.

${ }^{5}$ Druk informacyjny The Kalevala Collection (University Library in Joensuu 2010). 


\section{Zmiany w systemie zarządzania jakością w Bibliotece Uniwersytetu Finlandii Wschodniej}

Zmiana struktury organizacyjnej biblioteki niosła ze sobą wyzwanie dla całego procesu zarządzania, $w$ tym także dla systemu zarządzania jakością usług bibliotecznych. Przed nowo powstałą BUFW pojawił się problem znalezienia takich rozwiązań w zakresie zarządzania organizacją które umożliwiłyby dalsze funkcjonowanie kilku - różnych pod względem profilu gromadzenia - bibliotek naukowych jako jednej instytucji.

Najpierw na Uniwersytecie $w$ Kuopio wprowadzono system ISO 9001:2000 , charakteryzujący się procesowym podejściem do zarządzania jakością na uczelni i ciągłym doskonaleniem tego systemu ${ }^{7}$. Następnie zaczęto przygotowywać się do wprowadzenia systemu zarządzania jakością w BUFW. Pierwszym krokiem było wyznaczenie menedżera ds. zarządzania jakością, który uczestniczył we wszystkich odbywających się na uczelni spotkaniach dotyczących tego problemu. Miało to zwrócić uwagę władz uczelni na rolę biblioteki, która powinna być postrzegana jako integralna część uniwersytetu ze względu na to, że wspomaga wszystkie podstawowe funkcje wynikające ze statutu uczelni: dydaktyczna, naukową i społeczną.

Oddelegowany pracownik biblioteki nawiązał współpracę ze specjalistami z Centrum Informatycznego, która przyczyniła się do zagwarantowania wyższej jakości obsługi dzięki lepszej znajomości baz danych i procesu wyszukiwawczego. Natomiast współpraca ze specjalistami z Centrum Szkoleniowego zapewniła bibliotece wsparcie w zakresie przeprowadzania szkoleń. Biblioteczny system zarządzania jakością obejmuje:

- gromadzenie i analizowanie danych statystycznych,

- pozyskiwanie informacji zwrotnych o usługach bibliotecznych i sposobie obsługi (ankiety, wywiady),

${ }^{6}$ ISO 9001:2000 - norma, którą mogą stosować wszystkie organizacje, niezależnie od ich wielkości i rodzaju. Ukierunkowana jest ona na zrozumienie i spełnienie wymagań klienta, a więc określonych potrzeb danej organizacji, przyjęcie podejścia procesowego, dostarczanie wyników skuteczności procesów oraz ich ciągłe doskonalenie, na podstawie obiektywnych pomiarów [online], [dostęp: 24.07.2012], dostępny w internecie: https://pl.wikipedia.org/wiki/ISO_9001.

7 W BUFW funkcjonuje obecnie norma ISO 9001:2008 [online], [dostęp: 24.07. 2012], dostępny w internecie: http://www.woodheadpublishing.com/en/book.aspx? bookID=2479\&ChandosTitle $=1$.

${ }^{8}$ J. Saarti, A. Juntunen, From the rhetoric of quality management to managing selforganizing processes: a case study on an expert organization, w: Advances in Library Administration and Organization, red. E.D. Garten, D.E. Williams, J.M. Nyce, S. Talja, t. 25, Oxford 2007, s. 97-112. 
- analizowanie osiągnięć pracowników podczas rocznej samooceny i oceny dokonywanej przez przełożonego,

- przeprowadzanie analiz porównawczych,

- ciagłe udoskonalanie metod zarządzania9.

Najważniejszym narzędziem statystycznym w systemie zarządzania jakością w BUFW jest Baza Danych Statystycznych Biblioteki Naukowej KITT (Tieteellisten kirjastojen tilastotietokanta, ang. Research Library Statistics Database). Baza ta została opracowana przez Bibliotekę Narodową Finlandii. Opiera się na międzynarodowych standardach systemu ISO 2789:2006 ${ }^{10}$. Zawiera informacje statystyczne o wszystkich fińskich bibliotekach uniwersyteckich, bibliotekach politechnicznych i bibliotekach specjalistycznych. Baza KITT dostarcza podstawowych informacji o organizacji, zbiorach bibliotecznych, sposobie korzystania z usług bibliotecznych, godzinach otwarcia, finansach i personelu bibliotek. Dane podlegające analizie obliczane są automatycznie przez system. Możliwe jest uzyskanie danych statystycznych bezpośrednio z systemu bibliotecznego na temat skatalogowanych kolekcji, zarejestrowanych użytkowników i wypożyczeń. Informacje finansowe i statystyczne dotyczące gromadzenia i wykorzystania elektronicznych zasobów bibliotecznych gromadzi także Fińska Elektroniczna Biblioteka Narodowa (FinELib). Wszystkie biblioteki mają własne sposoby zbierania danych statystycznych, które opierają się na wytycznych krajowych ${ }^{11}$.

Jednym z najważniejszych narzędzi badawczych, wprowadzanym w związku z zapoczątkowaniem nowego systemu zarządzania jakościa, jest możliwość systematycznej kontroli skuteczności zarządzania. W tym celu powstał dwufazowy system, który funkcjonuje w następujący sposób: na początku roku planowane są działania na cały rok, a pod koniec roku następuje sprawdzenie rzeczywistego stanu przez analizę wszystkich danych i uwag zebranych od czytelników. Oprócz przeglądu statystyk i wyników badań weryfikowane są roczne sprawozdania zespołów zadaniowych, które koncentrują się na analizie informacji zwrotnej od użytkowników na temat usług oraz ocenie zmian wprowadzonych zgodnie z wymaganiami użytkowników.

Wykorzystywany jest także model EFQM (European Foundation for Quality Management - rys. 1), który został stworzony w celu przeprowa-

${ }^{9}$ J. Saarti, A. Juntunen, A. Taskinen, op.cit., s. 42.

${ }^{10}$ ISO 9001:2000 - norma, która określa zasady gromadzenia i przekazywania danych statystycznych w bibliotekach. Powstała w celu zapewnienia zgodności danych statystycznych w odniesieniu do międzynarodowej sprawozdawczości bibliotek [online], [dostęp: 24.07.2012], dostępny w internecie: http://eprints.rclis.org/bitstream/10760/17340/1/derfert_gorski_lodz_2008.pdf.

${ }^{11}$ J. Saarti, A. Juntunen, A. Taskinen, op.cit., s. 42. 
dzenia analizy dotyczącej korelacji między działaniami organizacji a uzyskanymi przez nią wynikami. Dzięki użyciu takiego modelu, będącego narzędziem oceny, możliwe jest określenie problemów i wskazanie kierunku rozwoju organizacji.

\section{Działania}

Wyniki
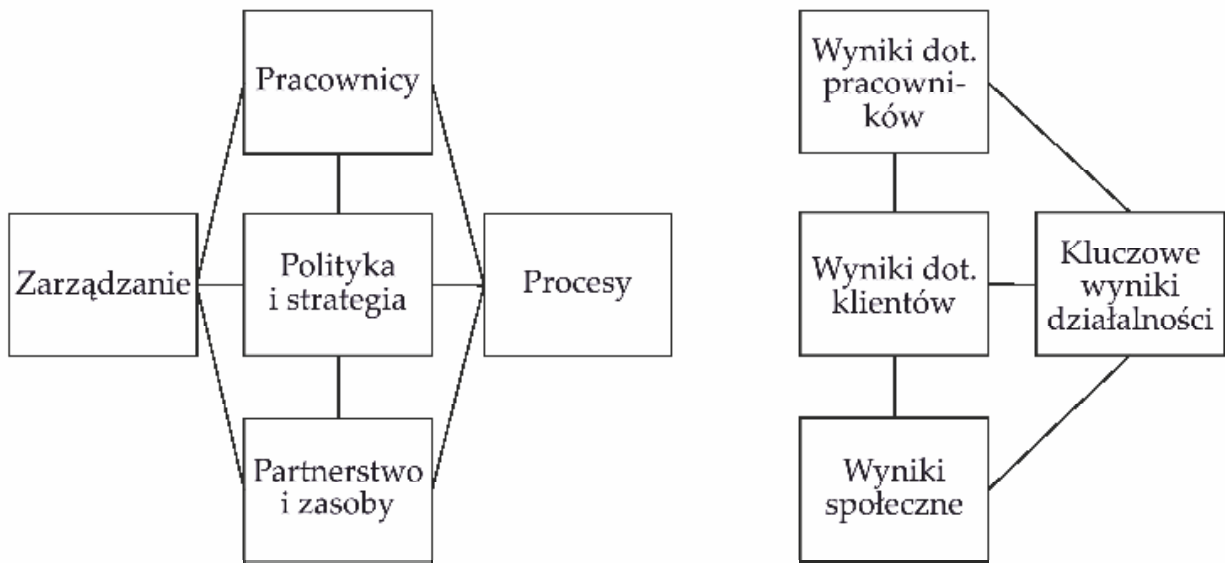

Rys. 1. Schemat modelu EFQM

Źródło: J. Saarti, A. Juntunen, A. Taskinen, Multi-faceted measuring of the quality as a tool for quality improvement in the Kuopio University Library, Finland, „Performance Measurement and Metrics" 2010, t. 11, nr 1, s. 43.

Wskaźniki dotyczące pracowników pochodzą z rocznego sprawozdania uniwersytetu na temat ich rozwoju, poziomu wykształcenia i kapitału wiedzy. Wskaźniki polityki i strategii opierają się na systemie zarządzania jakością, włączając audyt i certyfikaty, strategię pracy, pracę zespołową oraz ocenę całego procesu. Wskaźniki zasobów dotyczą materiałów bibliotecznych (ilość, jakość i język przekazu), czynników ekonomicznych, narzędzi badawczych (w tym technologii informacyjnych) i badanej przestrzeni (wielkość, funkcjonalność, czystość). Wskaźniki procesowe należą do najważniejszych i oparte są na wewnętrznej analizie podstawowych procesów biblioteki. W tym przypadku badane są następujące parametry:

- przydatność materiałów bibliotecznych,

- szkolenia dla użytkowników,

- logistyka,

- obsługa użytkowników,

- systemy komputerowe,

- usługi informacyjne,

- pomieszczenia biblioteczne. 
Końcowy wynik jest sumą składowych elementów analizy dotyczących pracowników, klientów i korzyści społecznych. Dla przykładu, badając personel, bierze się pod uwagę liczbę nieobecności, atmosferę w miejscu pracy, rotację pracowników, liczbę odbytych szkoleń, rozwój kariery. Badania użytkowników dokonuje się pod kątem prowadzonych cyklicznie statystyk i analiz, postępów studentów w nauce i analizy wpływu, jaki biblioteka wywiera na podstawowe obszary działalności uczelni.

Zestawienie wyników to najistotniejsza część analizy, która podlega ciągłemu monitorowaniu pod względem:

- zbiorów biblioteki w stosunku do potrzeb użytkowników,

- korzystania z biblioteki (statystyki),

- kompetencji pracowników,

- dydaktyki,

- metod zarządzania (np. analiza porównawcza z innymi bibliotekami akademickimi).

Większość badań przeprowadzana jest na podstawie systemu komputerowego i jest analizowana raz do roku. Pozostałe ankiety i inne czasochłonne pomiary wykonywane są co dwa, trzy lata, zależnie od potrzeby.

Model EFQM w pełnej formie nie funkcjonuje jeszcze w BUFW, jest natomiast wykorzystywany w formie testowej w Bibliotece Uniwersyteckiej w Kuopio. Aby stał się efektywnym narzędziem systemu zarządzania jakością, należy udoskonalić metody badań statystycznych w zakresie gromadzenia i analizy danych, ponieważ baza KITT nie zawiera wszystkich niezbędnych wskaźników ${ }^{12}$.

Badania satysfakcji użytkowników przeprowadzane w Bibliotece Uniwersyteckiej w Kuopio można podzielić na dwie kategorie: regularne i specjalistyczne. Służą one monitorowaniu potrzeb użytkowników w zakresie gromadzenia i korzystania ze zbiorów bibliotecznych. Okazuje się, że wykonywane trzy razy w roku badania najlepiej służą poznaniu potrzeb użytkowników. W wyniku regularnych badań udało się podjać strategiczną decyzję dotyczącą przejścia z czasopism drukowanych na elektroniczne oraz zreorganizowania instytucji ze zorientowanej na gromadzenie na taka, która jest nastawiona na klienta. Specjalnie dostosowane badania potrzeb użytkowników zostały przeprowadzone w celu sprawdzenia skuteczności nowych usług i ich funkcjonalności ${ }^{13}$.

12 Ibidem, s. 43-45.

${ }^{13}$ J. Kananen, T. Ovaska, J. Saarti, Collection policy management for the Kuopio University and Kuopio University Hospital, Finland: detecting the needs of users and developing high-quality collections, "Health Information and Libraries Journal” 2006, t. 23, nr 3, s. 179-188. 
Niewątpliwie wdrożenie systemu zarządzania jakością było warte wysiłku. Wśród pracowników wyraźnie zauważono wzrost motywacji do pracy i doskonalenia umiejętności. W sferze zarządzania udało się obrać kierunek przywództwa wskazujący na ważną rolę biblioteki w strukturze uczelni. Natomiast na poziomie świadczenia usług zweryfikowano dotychczas oferowane usługi, a ich funkcjonowanie oparto na systemie ciągłego doskonalenia.

Zakładano, że system zarządzania jakością będzie skutecznie zaprojektowany i funkcjonalny. Zebrane dane służą kadrze zarządzającej i pozostałym pracownikom do podejmowania decyzji i szukania nowych rozwiązań. Wszystkie płaszczyzny badania, tj. przeprowadzanie ankiet, analiza danych statystycznych oraz inne jakościowe metody badawcze, są istotne dla całego procesu zarządzania jakością ponieważ dostarczają potrzebnych informacji, stanowią narzędzie identyfikacji pozornie drobnych zmian, które kiedyś mogą zrewolucjonizować usługi. Odpowiednio analizowane i interpretowane dane mogą pomóc bibliotece $\mathrm{w}$ lobbingu wewnętrznym i zewnętrznym. Wykaz danych świadczy także o wkładzie biblioteki w rozwój działalności badawczej oraz procesu dydaktycznego uczelni, jak również pomaga przekonać władze uniwersytetu do przyznawania środków na rozwój poszczególnych usług.

Analiza porównawcza fińskich bibliotek uniwersyteckich wykazała, że BUFW plasuje się w pierwszej piątce faworytów i że ciągle doskonali swoje usługi, a przez to poprawia własny wizerunek ${ }^{14}$.

\section{Zmiany w systemie gromadzenia, przechowywania i udostępniania księgozbioru w Bibliotece Uniwersytetu Finlandii Wschodniej}

Kolejnym wyzwaniem, przed którym stanęły poszczególne jednostki $\mathrm{w}$ obliczu połączenia $\mathrm{w}$ jedną instytucję, był charakter gromadzonego księgozbioru. Przyjęto, że w bibliotece w Kuopio w związku z tym, że większość prowadzonych w tym kampusie kierunków studiów ma charakter ścisły, księgozbiór organizowany będzie wokół baz danych i elektronicznych źródeł informacji. Natomiast w bibliotece w Joensuu, gdzie większość kierunków studiów ma charakter humanistyczny, skupiono się na gromadzeniu księgozbioru w postaci drukowanej.

${ }^{14}$ N. Balague, J. Saarti, Benchmarking quality systems in two European academic libraries, „Library Management” 2009, t. 30, nr 4/5, s. 237. 
Z powodu mających nastąpić zmian związanych z fuzją bibliotek na stronie internetowej BUFW umieszczono szczegółowy opis usług oferowanych czytelnikom oraz opis regulaminu dotyczącego wypożyczania materiałów bibliotecznych i korzystania z usług każdej biblioteki.

Schemat obiegu materiałów bibliotecznych przedstawia rysunek 2.

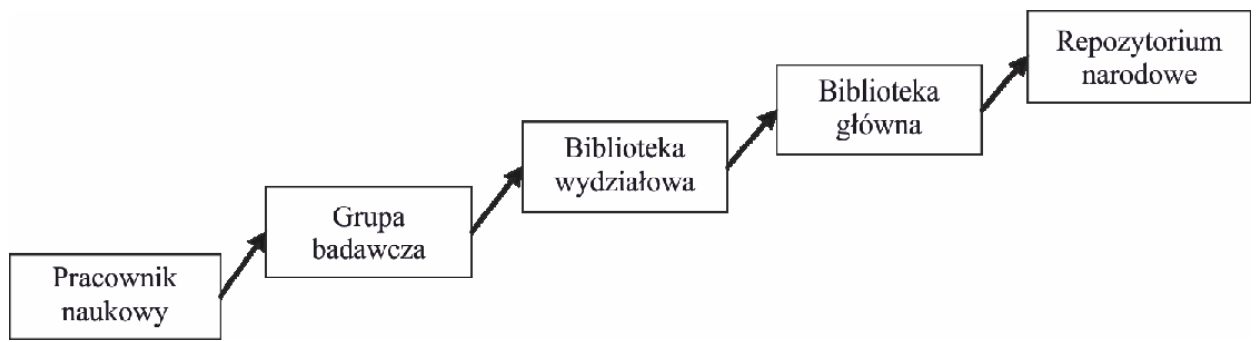

Rys. 2. Schemat obiegu materiałów bibliotecznych w BUFW

Źródło: A. Muhonen, J. Saarti, J. Vattulainen, Managing the life cycles of the document and library collections in Finnish academic libraries, „Library Management” 2010, t. 31, nr 8/9, s. 673.

Sygnał o zakupie potrzebnej literatury z danej dziedziny pochodzi od pracownika naukowego. Następnie z tego materiału korzysta najczęściej grupa badawcza, zajmująca się danym zagadnieniem. Materiał ten dostępny jest początkowo w bibliotece wydziałowej, następnie w bibliotece głównej, wreszcie zostaje przewieziony do repozytorium narodowego (National Repository Library - NRL).

Zarządzanie obiegiem dokumentów i systemem magazynowania także wymagało wprowadzenia wielu zmian. Jak wiadomo, system upowszechniania materiałów bibliotecznych przez ostatnie dwie dekady zmienił się radykalnie. Można wręcz mówić o cyfrowym łańcuchu rozpowszechniania publikacji. W związku z łatwiejszym dostępem i przechowywaniem dokumentów elektronicznych konieczne stało się również digitalizowanie materiałów gromadzonych dawniej jedynie w wersji drukowanej. Kultura książek drukowanych znajduje się na rozdrożu: wiele książek wydaje się drukiem, a jednocześnie rośnie liczba książek digitalizowanych. Niezależnie jednak od tego, czy przyszłość bibliotek będzie częściowo czy wyłącznie oparta na digitalizacji, problem wypracowania skutecznej polityki gromadzenia i zarządzania przechowywaniem materiałów bibliotecznych, zwłaszcza tych mniej używanych, będzie nadal istniał.

NRL zostało utworzone przez Ministerstwo Edukacji w 1989 roku. Zarząd repozytorium narodowego powoływany jest raz na trzy lata, a budżet wynosi 1,6 miliona euro. Suma ta stanowi 6,8\% budżetu, którym dysponują fińskie biblioteki uniwersyteckie na gromadzenie i 1,6\% całego 
budżetu wszystkich bibliotek naukowych w Finlandii. Celem powstania repozytorium było stworzenie możliwie najekonomiczniejszego sposobu przechowywania księgozbioru dla wszystkich bibliotek na terenie kraju. Materiał spływający z fińskich bibliotek do repozytorium narodowego staje się jego własnością. Obecnie NRL posiada $20 \%$ zasobu zgromadzonego przez biblioteki naukowe, specjalistyczne i publiczne ${ }^{15}$.

Głównym zadaniem NRL jest wspomaganie biblioteki w udostępnianiu i magazynowaniu zbiorów. Narodowe repozytorium udostępnia materiały naukowe, stanowi ogniwo łączące wszystkie typy bibliotek. W odniesieniu do BUFW umożliwia zamówienie materiałów bibliotecznych z NRL do każdej biblioteki wydziałowej. Zamówienia dla bibliotek poszczególnych kampusów realizowane są codziennie za pomocą samochodów poczty uniwersyteckiej. Koszty transportu pokrywa uczelnia.

NRL stanowi swego rodzaju centrum udostępniania. Od 1996 roku repozytorium narodowe jest największym w całej Finlandii dostawcą wypożyczeń międzybibliotecznych. Usługa ta, obejmująca także przesyłanie kopii artykułów, nie podlega opłacie. Użytkownicy za pomocą poczty elektronicznej otrzymują w ciągu 24 godzin skany zamówionych publikacji $\mathrm{w}$ formacie PDF. NRL otrzymuje rocznie około 80 tysięcy zamówień dotyczących wypożyczeń. Większość z nich to zamówienia materiałów zwartych przychodzące z bibliotek publicznych (66\%). Zamówienia na kopie artykułów pochodzą głównie z bibliotek naukowych (90\%). Repozytorium narodowe przez udostępnianie materiałów bibliotecznych wspomaga politykę gromadzenia poszczególnych bibliotek. Dzięki temu modelowi fińskie biblioteki naukowe mogą kontrolować przestrzeń magazynowa a przez to zaoszczędzić nawet 3,5 miliona euro rocznie. Przetransportowały one do NRL materiały biblioteczne, które ustawione na półkach zajmują $111 \mathrm{~km}$, co odpowiada 23 tysiącom $\mathrm{m}^{2}$. W repozytorium narodowym obowiązuje koncepcja long tail, którą jako pierwszy, w październiku 2004 roku, sformułował Chris Anderson w celu opisania modeli biznesowych i ekonomicznych, zaobserwowanych w działalności takich firm jak Amazon.com czy Netflix. Zgodnie z nią posiadanie szerokiego asortymentu może zaowocować wygenerowaniem pojedynczych, rzadko poszukiwanych dóbr, które przyniosą większe zyski niż najpopularniejsze, masowe towary. Tę strategię można przenieść na grunt biblioteczny w odniesieniu do większego wykorzystania nowo zgromadzonych materiałów bibliotecznych oraz mniejszego wykorzysta-

15 Strona internetowa National Repository Library [online], [dostęp: 1.06.2012], dostępny w internecie: http://www.varastokirjasto.fi/lang_en/. 
nia zasobów wcześniej zgromadzonych, które stanowią wyzwanie dla procesu magazynowania ${ }^{16}$.

W kampusie Biblioteki Uniwersyteckiej w Kuopio zdecydowano się zredukować powierzchnię magazynu o 2/3 i przeznaczyć ją dla czytelników. Było to możliwe dzięki wprowadzeniu nowej strategii magazynowania zbiorów bibliotecznych, która opierała się właśnie na przewiezieniu mniej wykorzystywanego księgozbioru do magazynów repozytorium narodowego. Połowa materiałów przechowywanych wcześniej w magazynach zamkniętych w kampusie w Kuopio została przewieziona do NRL. W wyniku takiej reorganizacji więcej nowości znalazło się na półkach bibliotecznych, a także udało się zmniejszyć koszty przeznaczone na przechowywanie zbiorów. Jednocześnie zwiększyła się liczba zdigitalizowanych dokumentów, co oznacza, że większość materiałów przeniesionych do repozytorium narodowego dostępna była także w wersji elektronicznej ${ }^{17}$.

Przewiezienie zbiorów do NRL spowodowało powiększenie przestrzeni magazynowej wszystkich bibliotek naukowych o 3\%. Tym samym całkowity obszar ich powierzchni użytkowej powiększył się o 23\%. W sześciu bibliotekach gromadzących egzemplarz obowiązkowy obszar powierzchni użytkowej wzrósł o 69\%, a przestrzeń magazynowa o 14\%. Natomiast w pozostałych 16 bibliotekach uniwersyteckich udało się całkowicie zlikwidować zamknięte magazyny. Spośród materiału gromadzonego $\mathrm{w}$ repozytorium narodowym $62,6 \%$ pochodzi z bibliotek uniwersyteckich, z czego $15 \%$ to zbiory zwarte, a $20,2 \%$ to czasopisma. Po zwiększeniu powierzchni NRL dysponuje wolną powierzchnią magazynową równą 70 km półek, co oznacza, że może pomieścić około 3 miliony zbiorów ${ }^{18}$.

\section{Zmiany w zakresie zarządzania zasobami ludzkimi}

Wśród pracowników biblioteki w Joensuu istniał większy aniżeli w bibliotece w Kuopio opór przed zmianą struktury organizacyjnej, a także przed wprowadzeniem zmian w zakresie zarządzania jakością usług bibliotecznych. Od razu zauważono tam potrzebę przeszkolenia personelu w celu odejścia od starego sposobu myślenia i zmniejszenia lęku przed zmianą.

${ }^{16}$ A. Muhonen, J. Saarti, J. Vattulainen, Managing the life cycles of the document and library collections in Finnish academic libraries, „Library Management” 2010, t. 31, nr 8/9, s. 671 .

17 J. Saarti, Challenges for Library space; space for books or space for users; the case of Kuopio University Library, "Journal of EAHIL” 2009, t. 5, nr 4, s. 3-5.

${ }^{18}$ A. Muhonen, J. Saarti, J. Vattulainen, op.cit., s. 671. 
Oznaczało to, że kompetencje i umiejętności bibliotekarzy będą przechodzić gwałtowną rewolucję. Dzisiejszy bibliotekarz ma wykształcenie wyższe, jest nowoczesnym menedżerem, skutecznym specjalistą od marketingu i znakomitym PR-owcem. Jednocześnie coraz istotniejsza staje się jego wiedza know-how z zakresu pozyskiwania funduszy i ekonomii. Wychodząc naprzeciw tym problemom, a jednocześnie mając na uwadze fuzję uniwersytetów i bibliotek, postanowiono wykorzystać potencjał pracowników BUFW jako organizacji uczącej się. W tym celu wyznaczono cztery strategiczne obszary działań takiej organizacji, odpowiadające zdobywaniu i doskonaleniu umiejętności przez personel biblioteczny. Są to poziomy występujące między organizacjami, w organizacji, w zespołach i wśród pracowników ${ }^{19}$.

Na poziomie między organizacjami chodzi o podkreślenie znaczenia biblioteki w podejmowaniu strategicznych decyzji na szczeblu zarówno krajowym, jak i międzynarodowym. Jednocześnie pracownicy, którzy odpowiadają za współpracę między bibliotekami w kraju i za granica, muszą posiadać odpowiednie umiejętności. Biblioteka, wychodząc naprzeciw tym potrzebom, organizuje warsztaty z zakresu zdobywania funduszy oraz kursy językowe. Jednym z założeń jej strategii jest pozyskiwanie partnerów w najlepszych bibliotekach w kraju i za granicą. Proces współpracy zagranicznej jest popierany przez uniwersytet, czego przejawem jest uczestnictwo w programie wymiany Erasmus, z którego mogą skorzystać wszyscy pracownicy. Osoby, które uczestniczyły w wymianie, są zobowiązane do przygotowania pisemnego raportu i przedstawienia go na zebraniu współpracownikom ${ }^{20}$. Poza tym pracownicy biblioteki uczestniczą w spotkaniach zespołów zadaniowych organizowanych na uniwersytecie. Należy podkreślić, że wizyty zarówno krajowe, jak i zagraniczne niosą ze sobą możliwość porównania metod zarządzania i ich doskonalenia w poszczególnych bibliotekach. Przykładem może być projekt realizowany przez bibliotekę Uniwersytetu Autonomicznego w Barcelonie i Biblioteką Uniwersytecką w Kuopio ${ }^{21}$.

Podczas fuzji bibliotek należało w sposób szczególny uwzględnić kolejny poziom - organizacyjny. Najważniejszymi jego elementami są: zarządzanie strategiczne, system komunikacji wraz z systemem obiegu dokumentów oraz współpraca zespołów zadaniowych. System komunikacji

19 A. Juntunen, J. Saarti, Bringing out the best of everyone: A systematic approach to the workplace coaching and learning at the Kuopio University Library, Finland, "Library Management" 2011, t. 32, nr 8/9, s. 580.

20 T. Ovaska, Professional development by work shadowing, "Journal of EAHIL" 2009, t. 5, nr 4, s. 45-46.

${ }^{21}$ N. Balague, J. Saarti, op.cit., s. 227-239. 
w rozproszonych, oddalonych od siebie o około $140 \mathrm{~km}$ jednostkach wymagał przeobrażenia. Oparto go na nowoczesnych technologiach wirtualnych, głównie wideokonferencjach. Powołano ponadto zespoły problemowe, których zadaniem było wdrażanie projektu systemu zarządzania jakością oraz przedstawianie sprawozdań ze swojej działalności wszystkim pracownikom bibliotek i uzyskiwanie od nich informacji zwrotnych. Dzięki współpracy na tym poziomie udało się BUFW opracować i wprowadzić w życie system zarządzania jakością oraz wypracować skuteczny system komunikacji wewnątrz biblioteki, a także $\mathrm{w}$ jej wszystkich jednostkach organizacyjnych. Włączenie do współpracy wszystkich pracowników niewątpliwie wpłynęło na poprawę relacji interpersonalnych. Poza tym pracownicy odczuli potrzebę podniesienia własnych kwalifikacji, a także zrozumieli konieczność nawiązywania skutecznej komunikacji z użytkownikami, tak żeby biblioteka w ich ocenie była instytucją przyjaźnie nastawioną do każdego czytelnika korzystającego z jej usług.

Trzeci poziom organizacji uczącej się to poziom zespołów, czyli poszczególnych działów odpowiedzialnych za wykonywanie codziennych zadań i świadczenie usług w bibliotece. Są one zobowiązane do przedstawiania rocznych sprawozdań i projektu planu na nadchodzący rok. Plan taki powstaje na podstawie głównych zasad funkcjonowania biblioteki i jej budżetu.

Ostatni poziom organizacji uczącej się dotyczy pracowników, na których zmiana kultury organizacyjnej wywarła największy wpływ. Wraz z wprowadzeniem nowego systemu zarządzania jakością wzrosły ich potrzeby szkoleniowe. Na uczelni odbyło się wówczas szkolenie z zakresu zarządzania dla wszystkich pracowników. Oprócz tego w NRL i w bibliotece w Savonlinna sporządzono swego rodzaju mapę umiejętności pracowników. Służący temu kwestionariusz przygotowany został przez Stowarzyszenie Fińskich Bibliotek Naukowych i dotyczy następujących kompetencji:

- w zakresie informacji naukowej,

- dydaktycznych,

- w zakresie obsługi użytkowników,

- w zakresie komunikacji interpersonalnej,

- kreatywnego nastawienia do pracy,

- w zakresie współpracy zagranicznej,

- przywódczych,

- w dziedzinie marketingu,

- umiejętności negocjacyjnych,

- językowych ${ }^{22}$.

${ }^{22}$ A. Juntunen, J. Saarti, op.cit., s. 582-585. 
Know-how każdego pracownika w poszczególnych dziedzinach oceniany jest $\mathrm{w}$ skali od 1 do 5 podczas rozmowy z prowadzącym badanie. Wynik na poziomie zero oznacza brak wymaganej kompetencji u pracownika, np. ze względu na krótki okres zatrudnienia. Punktacja 1-3 wskazuje na opanowanie danej kompetencji na wymaganym poziomie. Natomiast wynik 4-5 wykazuje posiadanie danej kompetencji na poziomie wyróżniającym i oznacza możliwość reprezentowania instytucji na szczeblu krajowym bądź międzynarodowym. Przed przystąpieniem do badania prowadzący wyjaśnia, w jaki sposób należy podejść do oceny poszczególnych kompetencji. Badanie jest przeprowadzane wśród wszystkich pracowników biblioteki w Kuopio. Mapowanie przedstawia obecny stan wiedzy i umiejętności zatrudnionych oraz wskazuje potrzebę rozwoju poszczególnych kompetencji w przyszłości. Na podstawie wyników można zaplanować szkolenia dla pracowników. Na wykresie (rys. 3) przedstawiono dane dotyczące kompetencji pracowników, zmierzone w grupie, która powinna je posiadać.

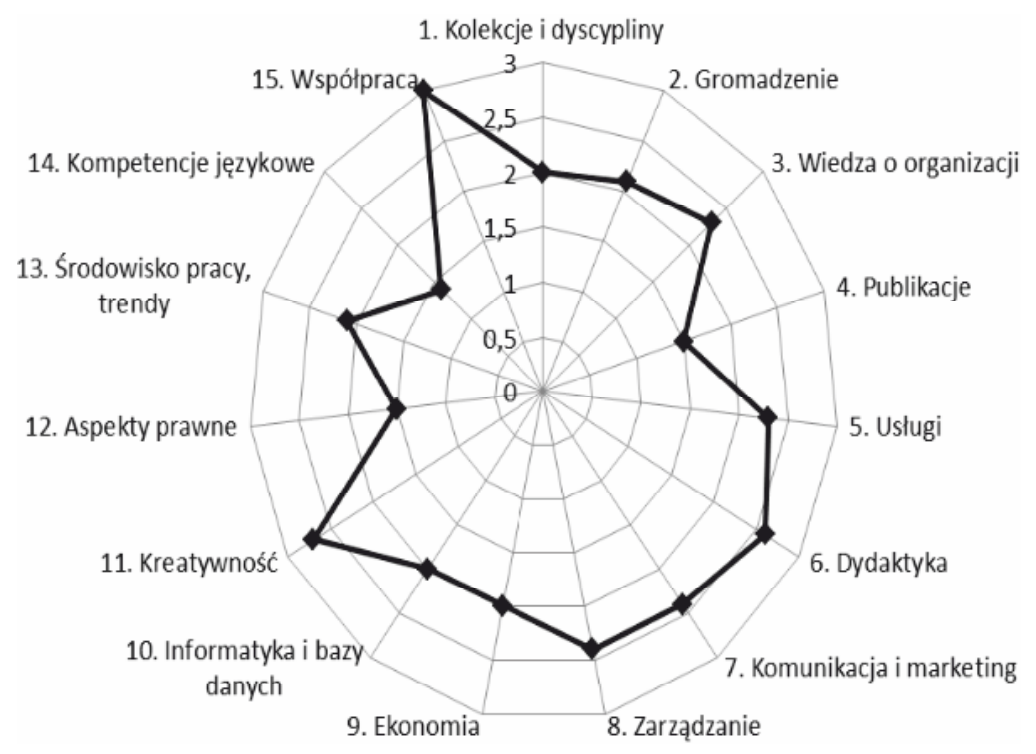

Rys. 3. Mapa kompetencji pracowników

Źródło: A. Juntunen, J. Saarti, Bringing out the best of everyone: A systematic approach to the workplace coaching and learning at the Kuopio University Library, Finland, „Library Management”, t. 32, nr 8/9, s. 586.

Rezultat badania pomaga ocenić, jakimi kompetencjami dysponują pracownicy biblioteki, określić ich poziom i adekwatność do zajmowanego stanowiska. Wyniki indywidualne każdego pracownika nie są 
ujawniane zgodnie z prawem ochrony danych osobowych. Niemniej jednak każdy pracownik biblioteki podlega corocznej ocenie i posiada własne CV, które składa się z następujących elementów: edukacja, szkolenia, kursy, przynależność do zespołów zadaniowych w bibliotece i na uczelni, publikacje, członkostwo w organizacjach. Dzięki temu możliwe jest dostosowanie systemu szkoleń indywidualnie do potrzeb każdego pracownika. System mapowania know-how wskazuje różnice między umiejętnościami poszczególnych pracowników. Jest on także pomocny podczas przeprowadzania procesu rekrutacji ${ }^{23}$.

\section{Konkluzje}

Organizacja ucząca się to „organizacja w ruchu”, ponieważ tworzy i przechowuje rozmaite informacje (o procesach, zasobach, procedurach) możliwe do wykorzystania w różnych sytuacjach oraz dywersyfikuje zasoby wiedzy, rozwijając eksploracyjne uczenie się, ciekawość, eksperymentowanie, podejmowanie ryzyka, wrażliwość na zjawiska zewnętrzne ${ }^{24}$. Obserwując zmiany w Bibliotece Uniwersytetu Finlandii Wschodniej związane z fuzją poszczególnych jednostek bibliotecznych, z powodzeniem można stwierdzić, że ma ona wszystkie cechy organizacji uczącej się, ponieważ w sposób ciągły i świadomy wspomaga proces uczenia się pracowników, a w rezultacie całej organizacji. BUFW gromadzi zasoby wiedzy w elastyczny sposób, umożliwiający ich szybkie uruchomienie i wykorzystanie bądź zapominanie, co stanowi podstawowy warunek umożliwiający funkcjonowanie biblioteki w warunkach turbulentnego otoczenia.

${ }^{23}$ Ibidem, s. 585.

${ }^{24}$ E. Stańczyk-Hugiet, op.cit., s. 222. 
"The library that learns" - changes
in the organization and the management system
at the Library of the University of Eastern Finland

\begin{abstract}
Aвstract. The ever-changing, dynamic and increasingly more and more demanding environment of the modern research library exerts pressure on innovative processes related to changes in the applicable managing model. The article discusses the changes in the organization and the managing system at the library of the University of Eastern Finland that had to be effected as a result of a merging process of individual library units into one. The article provides a description of a number of the said transformations at the level of the organizational structure, acquisition policy, storage and circulation of resources and at the level of human resources management within the context of the concept of the institution that has to learn in the process and can adjust itself to unstable environment and the following changes. Within this concept, the library is also to be in position to be ready to adopt alternative solutions that would secure continuity and further development of the institution.
\end{abstract}

KEY wORDS: Library of the University of Eastern Finland, Kuopio University Library, Joensuu University Library, institution that learns, change. 